\title{
IDENTIFIKASI STRUKTUR SISTEM PANAS BUMI PANTAR BERDASARKAN ANALISIS GRADIEN HORIZONTAL DAN PEMODELAN 3D DATA GAYA BERAT
}

\section{IDENTIFICATION OF PANTAR GEOTHERMAL STRUCTURES DERIVED FROM GRADIENT HORIZONTAL ANALYSIS AND 3D MODELING OF GRAVITY DATA}

\author{
Asep Sugianto, Iqbal Takodama, dan Tony Rahadinata \\ Pusat Sumber Daya Mineral, Batubara dan Panas Bumi \\ asep.soegie@gmail.com
}

\begin{abstract}
ABSTRAK
Reservoir panas bumi umumnya berasosiasi dengan struktur sesar (zona permeabel), sehingga identifikasi struktur sesar untuk merekonstruksi sistem panas bumi menjadi sangat penting. Salah satu metode yang dapat digunakan untuk mengidentifikasi struktur tersebut adalah dengan melakukan analisis gradient horizontal dan pemodelan 3D data gaya berat. Kedua metode tersebut telah diaplikasikan untuk mengidentifikasi struktur sesar di daerah panas bumi Pantar yang terletak di Pulau Pantar, Kabupaten Alor, Nusa Tenggara Timur. Daerah tersebut berasosiasi dengan Gunung Api Sirung yang membentuk kaldera berdiameter $3 \mathrm{~km}$ dan secara umum tersusun atas batuan vulkanik berupa lava dan piroklastik serta batuan sedimen. Hasil analisis gradien horizontal data gaya berat memperlihatkan adanya magnitudo maksimum di sekitar daerah Puriali, Tubbe, Beang, dan di bagian timurlaut daerah survei. Hasil pemodelan gaya berat 3D memperlihatkan kontras densitas batuan di sekitar magnitudo maksimum yang mengindikasikan pada zona tersebut terdapat struktur sesar. Struktur sesar tersebut juga diduga menjadi pengontrol kemunculan beberapa manifestasi panas bumi di permukaan. Pola magnitudo maksimum yang landai mengindikasikan banyaknya sesar minor di sekitar sesar utama yang berarah baratdayatimurlaut di sekitar mata air dingin Sirung dan tanah panas Puriali. Kondisi tersebut menyebabkan zona di sekitar struktur sesar memiliki permeabilitas tinggi dan sangat baik untuk menyimpan fluida panas sebagai suatu reservoir panas bumi.
\end{abstract}

Kata kunci: analisis gradien horizontal, pemodelan 3D, gaya berat,panas bumi, Pantar

\section{ABSTRACT}

Geothermal reservoir is commonly associated with fault structures zone. So, fault structure identification is very important to reconstruct geothermal system. Horizontal gradient analysis and $3 D$ modeling from gravity data is some methods that can be used to identifying fault structures in geothermal areas. The method has applied to identify fault structures in Pantar geothermal field, in Pantar Island, Alor Regency, East Nusa Tenggara. Result of gravity horizontal gradient analysis show maximum magnitude at Puriali, Tubbe, Beang, and northeastern part of survey area. Result of $3 D$ gravity modeling show contrast of density around maximum magnitude zones that indicated fault structures. The maximum magnitude is associated with surface thermal manifestations indicated that they are controlled by the fault structures. The pattern of maximum magnitude is not spike that indicated many minor structures around main structures that caused the zone has high permeability and is very good for storing the geothermal fluids.

Keywords: horizontal gradient analysis, 3D modeling, gravity,geothermal, Pantar. 


\section{MAKALAH ILMIAH}

\section{PENDAHULUAN}

Pulau Pantar merupakan salah satu pulau yang terletak di Kabupaten Alor, Provinsi Nusa Tenggara Timur (Gambar 1). Di pulau ini terdapat Gunung Sirung yang merupakan gunung api aktif dengan aktivitas terakhir berupa letusan freatik pada tahun 2004 (Surmayadi dkk., 2010). Selain itu, di pulau ini juga terdapat manifestasi panas bumi berupa fumarol, mata air panas dengan temperatur berkisar antara $37^{\circ} \mathrm{C}$ sampai dengan $100^{\circ} \mathrm{C}$, tanah panas, dan batuan ubahan (Hadi dan Kusnadi, 2015). Kenampakan manifestasi tersebut menjadi indikasi adanya potensi energi panas bumi yang dapat dimanfaatkan baik secara langsung maupun secara tidak langsung.

Untuk mengetahui besarnya potensi panas bumi di daerah tersebut, telah dilakukan beberapa penelitian, diantaranya inventarisasi kenampakan panas bumi di Pulau Pantar dan Pulau Alor (Santoso, 1976), penyelidikan pendahuluan geologi dan geokimia di Pulau Pantar (Anonim, 2001), survei geologi dan geokimia (Hadi dan Kusnadi, 2015), survei gaya berat dan Audio Magnetotelurik (Rahadinata dan Takodama, 2015), dan survei magnetotelurik (Rahadinata dkk., 2016).
Suatu sistem panas bumi tipe hidrotermal umumnya dikontrol oleh struktur sesar, karena di sekitar zona sesar tersebut terbentuk banyak kekar-kekar yang menyebabkan zona (lapisan) batuan menjadi bersifat permeabel (Curewitz dan Karson, 1997). Pada zona permeabel inilah fluida panas bumi umumnya terakumulasi dan berinteraksi dengan batuan di sekitarnya. Karena itu, identifikasi zona sesar pada suatu sistem panas bumi menjadi suatu hal yang sangat penting, terutama untuk merekonstruksi model sistem panas bumi (Nishijima dan Naritomi, 2015).

Banyak metode yang dapat digunakan untuk mengidentifikasi zona struktur sesar tersebut diantaranya dengan melakukan analisis gradien horizontal data gaya berat seperti yang telah dibahas oleh Setyawan, dkk. (2015) dan Kusumah dkk. (2015). Metode lain adalah pemodelan data gaya berat 2D atau 3D (Sugianto dan Rahadinata, 2015).

Pada makalah ini dijelaskan mengenai analisis gradien horizontal dan pemodelan 3D data gaya berat untuk mengidentifikasi struktur sesar yang mengontrol sistem panas bumi daerah Pantar.

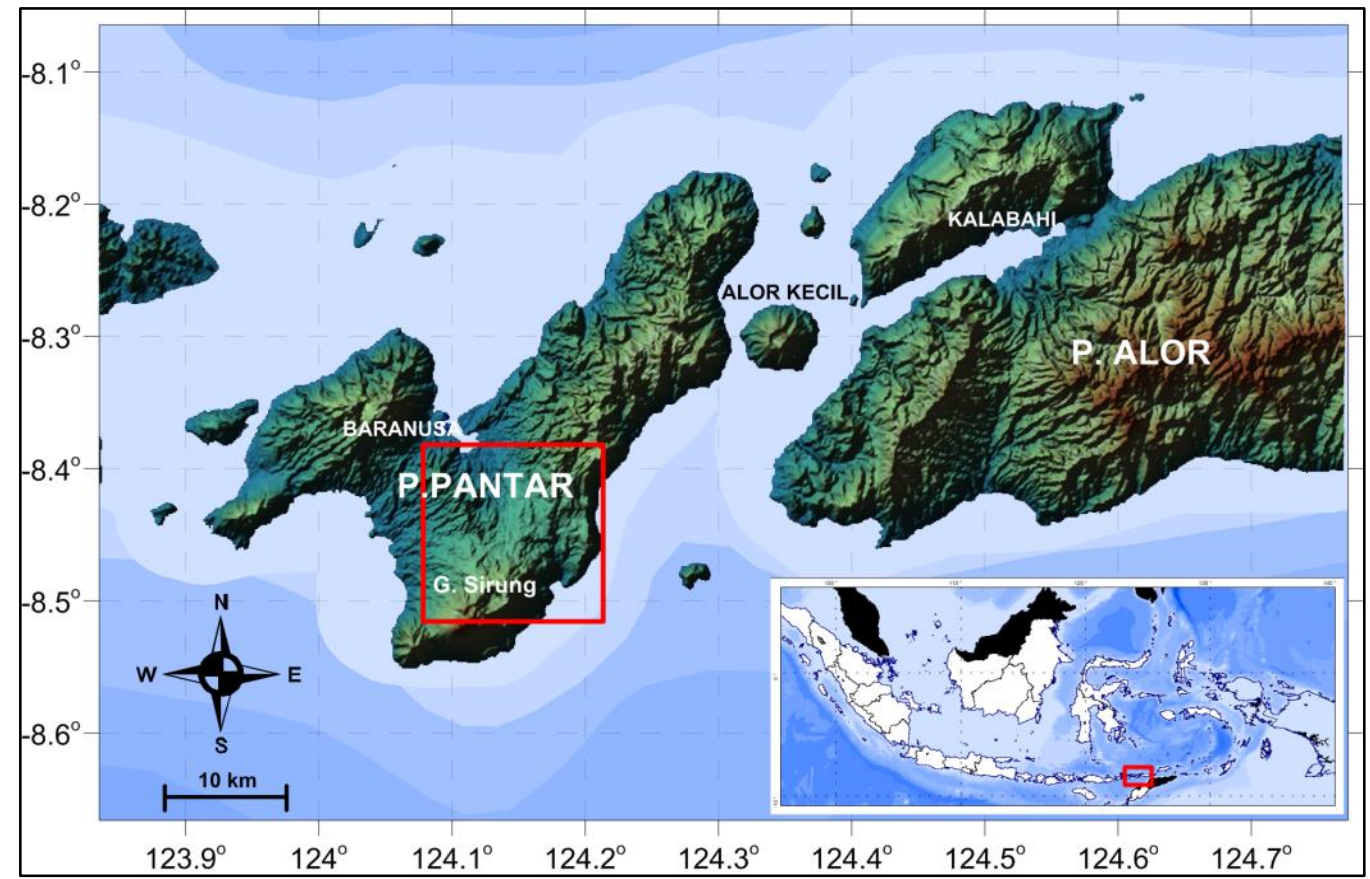

Gambar 1. Peta indeks daerah panas bumi Pantar Kabupaten Alor, Nusa Tenggara Timur 


\section{GEOLOGI DAERAH PANAS BUMI PANTAR}

Daerah panas bumi Pantar berasosiasi dengan Gunungapi Sirung yang berada dalam kaldera berdiameter $3 \mathrm{~km}$. Satuan batuan di daerah tersebut umumnya tersusun atas produk vulkanik berupa lava dan piroklastik serta batuan sedimen (Hadi dan Kusnadi, 2015). Batuan tertua berupa produk vulkanik Kongmaewas dan Kalondama yang terdapat di sebelah utara dan timur yang disertai dengan adanya pengendapan batuan sedimen berupa batugamping.

Produk berikutnya adalah aktifitas pembentukan pra kaldera Sirung yang tersusun atas produk vulkanik Boyali dan Mauta di bagian selatan dan produk Sirung Tua yang terdapat di bagian tengah hingga ke Pantai Beang. Erupsi besar terjadi di antara puncak Sirung dan Boyali yang menghasilkan piroklastik dan lava basal. Erupsi tersebut menyebabkan adanya kekosongan massa di bagian tengah, sehingga amblas dan membentuk kaldera Sirung. Aktivitas vulkanisme berikutnya muncul di sekitar dinding kaldera membentuk lava Sirung dan di luar kaldera membentuk Bukit Beang. Produk termuda berupa lava Sirung yang terdapat di bagian tengah kawah Sirung (Hadi dan Kusnadi, 2015) (Gambar 2).

Struktur utama yang berkembang di daerah ini umumnya sesar berarah utara-selatan yang berhubungan dengan aktifitas tektonik regional Pantar-Alor. Struktur lain berupa struktur yang diakibatkan oleh aktivitas vulkanik seperti kaldera yang terdapat di sekitar puncak Gunung Sirung. Selain itu, ditemukan juga struktur sesar yang berarah baratdaya-timurlaut. Aktivitas strukturstruktur tersebut diduga membentuk zona permeabel yang memungkinkan fluida panas bumi terakumulasi dan muncul ke permukaan sebagai mata air panas atau fumarol.

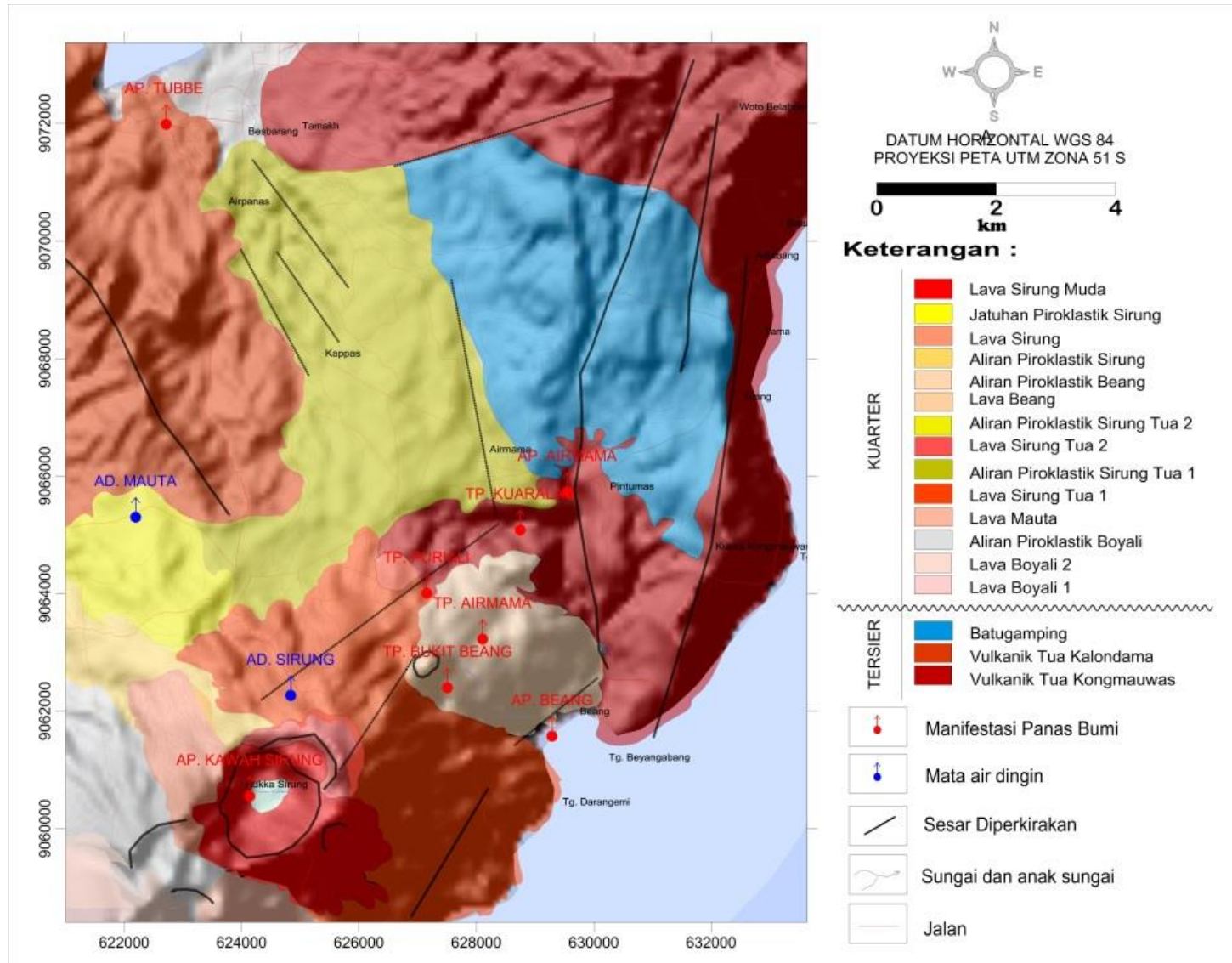

Gambar 2. Peta geologi daerah panas bumi Pantar (modifikasi dari Hadi dan Kusnadi, 2015) 


\section{METODOLOGI}

Gaya berat merupakan salah satu metode geofisika yang memanfaatkan gaya tarik bumi terhadap benda di permukaan. Metode tersebut dapat digunakan untuk mengetahui variasi densitas batuan di bawah permukaan bumi (Santos dan Rivas, 2009). Kontras densitas/anomali gaya berat secara lateral akan menimbulkan adanya gradien horizontal dari anomali gaya berat (Blakely, 1996). Karakteristik anomali gaya berat yang menunjukkan adanya perubahan secara lateral tersebut dapat diekstrak secara langsung dari data pengukuran gaya berat (Cordell, 1979), yaitu dengan cara menentukan amplitudo gradien horizontal anomali gaya berat yang dapat dinyatakan dengan persamaan (Cordell dan Grauch, 1985):

$$
H G=\sqrt{\left(\frac{\partial g_{(x, y)}}{\partial x}\right)^{2}+\left(\frac{\partial g_{(x, y)}}{\partial y}\right)^{2}}
$$

Keterangan: $\left(\frac{\partial g}{\partial x}\right)$ dan $\left(\frac{\partial g}{\partial y}\right)$ merupakan horizontal derivative medan gravitasi pada arah $\mathrm{x}$ dan arah $\mathrm{y}$.

Dalam mengindentifikasi variasi densitas di bawah permukaan, dilakukan juga interpretasi secara kuantitatif dengan menggunakan pemodelan data gaya berat secaratiga dimensi (3D), seperti yang telah dibahas oleh Sugianto dan Rahadinata (2015). Pemodelan gaya berat 3D tersebut didasarkan pada dua metode inversi, yaitu Singular Value Decomposition (SVD) dan inversi Occam (Hjelt, 1992) yang tersedia di dalam perangkat lunak Grablox dari Pirttijarvi (2004).

\section{HASIL DAN ANALISIS}

\section{Hasil}

Pengukuran data gaya berat daerah panas bumi Pantar telah dilakukan pada tahun 2015. Pengukuran dilakukan pada 204 titik ukur yang tersebar secara acak dengan jarak antar titik sekitar 1000 m (Rahadinata dan Takodama, 2015). Penghitungan anomali Bouguer dilakukan dengan menggunakan asumsi densitas $2,7 \mathrm{gr} / \mathrm{cm}^{3}$. Peta anomali Bouguer hasil penghitungan diperlihatkan oleh Gambar 3. Anomali Bouguer tersebut memperlihatkan pola anomali positif dengan rentang nilai dari 114 $\mathrm{mGal}$ hingga $148 \mathrm{mGal}$. Anomali rendah $<128 \mathrm{mGal}$ terletak di sebelah barat dan menerus hingga ke bagian utara, sedangkan anomali tinggi $>136 \mathrm{mGal}$ terletak di bagian selatan dan timur (Rahadinata dan Takodama, 2015).

Magnitudo gradien horizontal data gaya berat di daerah panas bumi Pantar dihitung dari anomali Bouguer pada domain frekuensi. Struktur sesar yang ditandai dengan adanya kontras densitas batuan umumnya memiliki magnitudo gradien horizontal yang maksimum. Akan tetapi, menurut Grauch dan Cordell (1987) magnitudo maksimum gradien horizontal tersebut dapat bergeser dari posisi sebenarnya apabila struktur sesar memiliki kemiringan yang landai (tidak mendekati vertikal) atau berdekatan dengan struktur sesar yang lainnya.

Peta gradien horizontal data gaya berat daerah Pantar diperlihatkan oleh Gambar 4. Pada peta tersebut ditemukan beberapa magnitudo maksimum yang berasosiasi dengan lokasi kemunculan manifestasi panas bumi, diantaranya di sekitar Airmama, Bukit Beang, Tubbe, dan Mauta. Kemunculan manifestasi di sekitar zona magnitudo maksimum mengindikasikan bahwa kemunculan manifestasi tersebut dikontrol oleh sesar. Ada beberapa magnitudo maksimum yang tidak bertepatan dengan sesar geologi, seperti di sebelah barat Puriali dan timurlaut daerah survei. Ketidaktepatan tersebut kemungkinan disebabkan oleh berdekatannya struktur sesar atau kemiringan sesar yang landai. 


\section{MAKALAH ILMIAH}

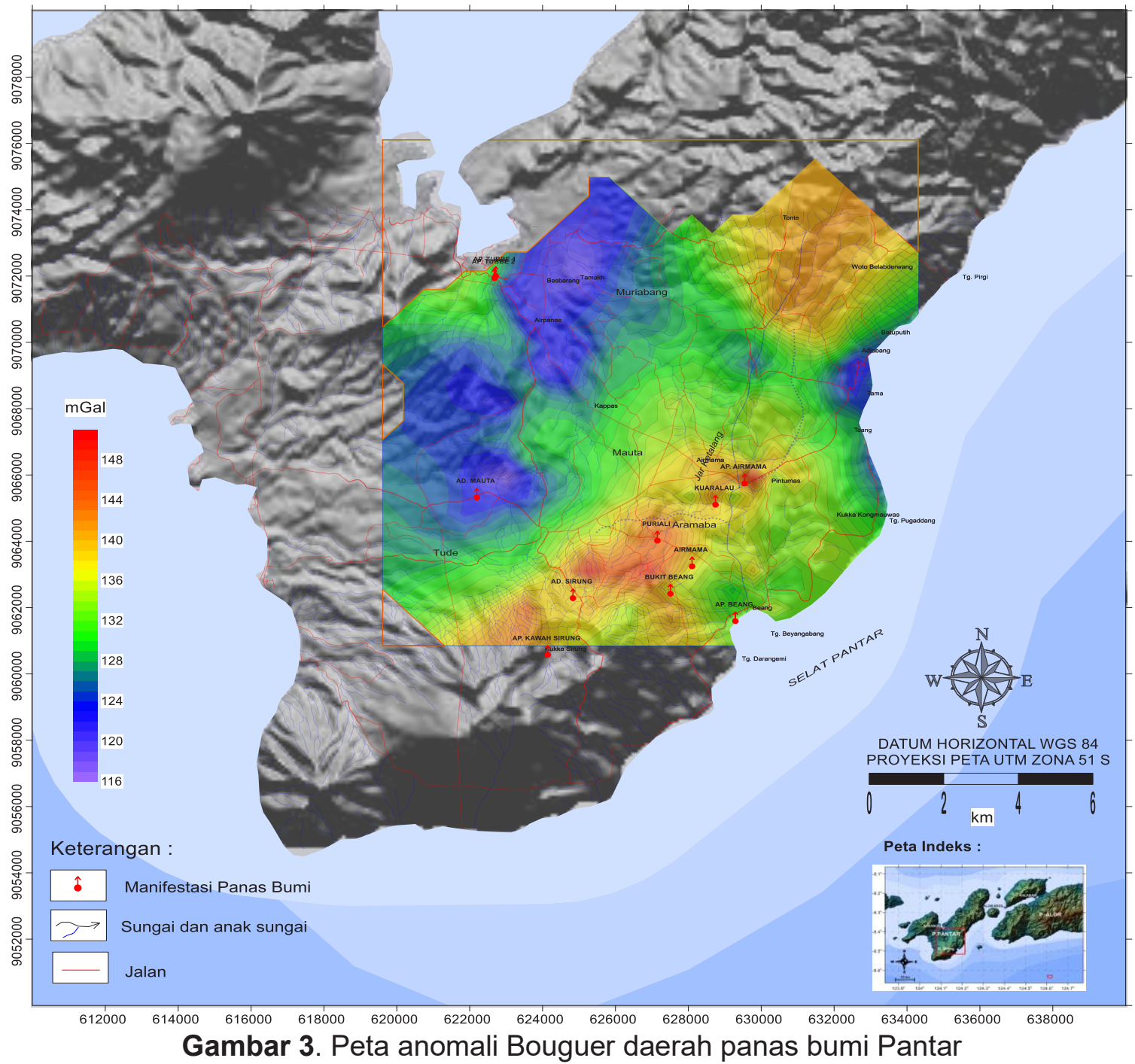

Pemodelan 3D data gaya berat dilakukan dengan menggunakan perangkat lunak Grablox (Pirttijarvi, 2004). Model awal dibuat berupa blok $13 \mathrm{~km} \times 14 \mathrm{~km}$ dengan ketebalan $4 \mathrm{~km}$. Blok tersebut dibagi ke dalam 33 sel $\times 35$ sel dengan ukuran sel sekitar $400 \mathrm{~m} \times 400 \mathrm{~m}$, sedangkan tebal blok tersebut dibagi ke dalam 7 kisi (grid) dengan ketebalan sekitar $570 \mathrm{~m}$. Densitas awal yang digunakan pada pemodelan tersebut adalah sebesar 2,67 $\mathrm{gr} / \mathrm{cm}^{3}$. Hasil pemodelan memperlihatkan respon baik, yang ditunjukkan dengan perbedaan antara input model (anomali Bouguer) dan hasil perhitungan (inversi) sangat kecil yang ditunjukkan dengan RMS error sebesar 0,023 .

Hasil pemodelan tersebut disayat pada kedalaman tertentu, yaitu kedalaman
500 m, 1000 m, 1500 m, 2000 m, 2500 m, dan $3000 \mathrm{~m}$ membentuk peta distribusi densitas batuan (Gambar 5). Peta distribusi densitas tersebut secara umum memperlihatkan pola sebaran yang relatif sama. Batuan berdensitas tinggi (besar dari $2,7 \mathrm{gr} / \mathrm{cm}^{3}$ ) tersebar di bagian selatan sekitar Airmama, Puriali, dan Beang dan di sebelah baratlaut dan timurlaut. Semakin dalam, batuan berdensitas tinggi tersebut memiliki penyebaran yang semakin luas. Batuan berdensitas rendah (kurang dari 2,7 $\mathrm{gr} / \mathrm{cm}^{3}$ ) terletak di sekitar daerah Mauta dan menerus hingga ke utara. Kontras batuan berdensitas tinggi dan rendah membentuk kelurusan-kelurusan yang berkorelasi dengan magnitudo maksimum gradien horizontal dan struktur sesar. 


\section{MAKALAH ILMIAH}

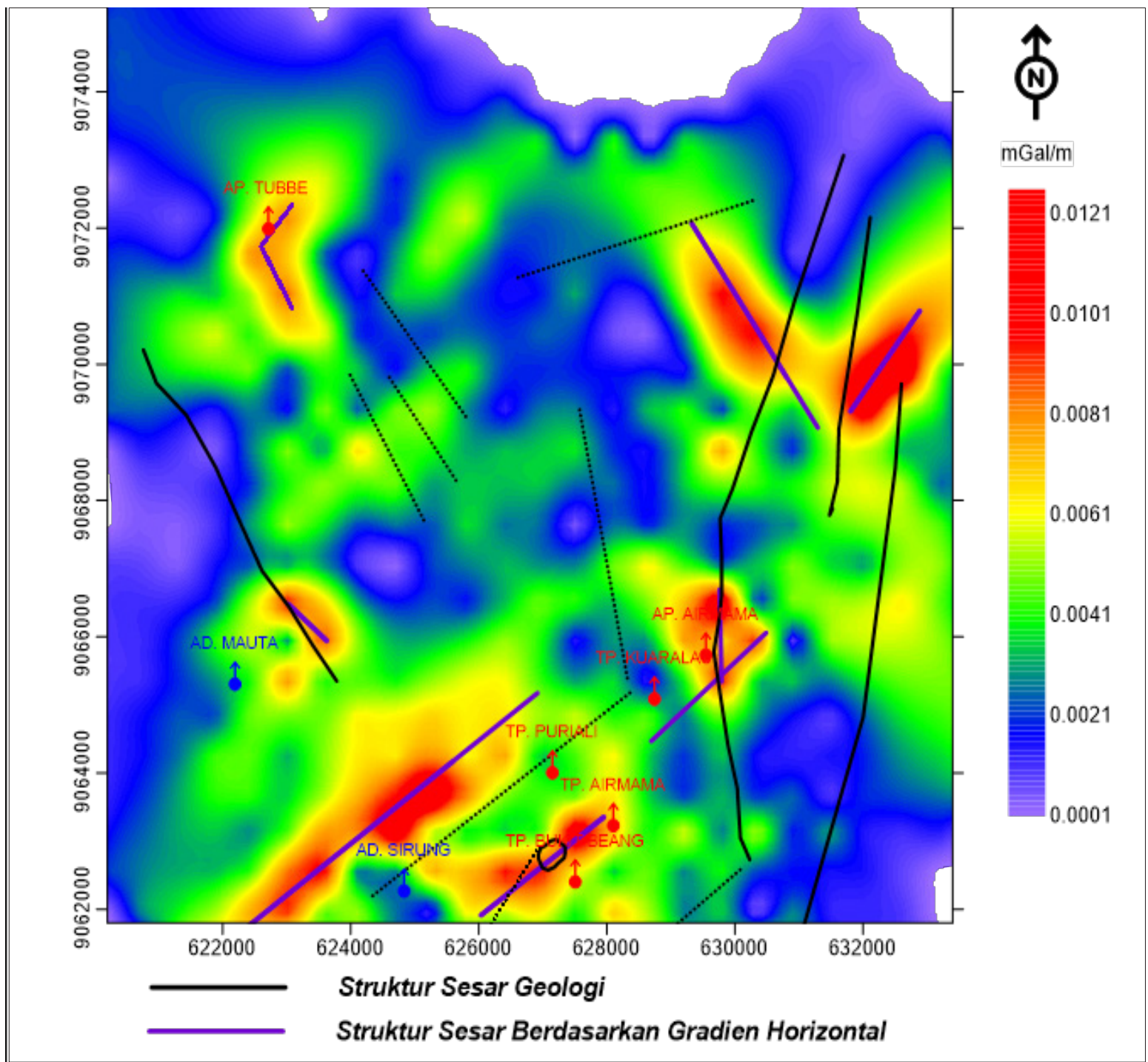

Gambar 4 Peta gradien horizontal data gaya berat daerah Pantar

\section{Analisis}

Hasil analisis gradien horizontal data gaya berat memperlihatkan magnitudo maksimum di sekitar Puriali, Tubbe, Airmama, Beang, dan di bagian timurlaut daerah survei. Magnitudo maksimum tersebut bertepatan dengan kontras densitas batuan hasil pemodelan gaya berat 3D yang mengindikasikan adanya struktur sesar (Gambar 6). Pada zona magnitudo maksimum juga terdapat manifestasi panas bumi berupa mata air panas, fumarol, dan tanah panas yang mengindikasikan bahwa kemunculan manifestasi tersebut dikontrol oleh struktur sesar yang berarah baratdayatimurlaut dan terletak di sekitar daerah Puriali, Kuarala, dan Airmama.
Magnitudo maksimum pada gradien horizontal membentuk pola yang tidak terlalu tajam (spike), tetapi cukup landai. Pola tersebut mengindikasikan bahwa struktur sesar memiliki kemiringan yang landai/tidak tegak atau terdapat beberapa struktur sesar yang berdekatan (Grauch dan Cordell, 1987). Berdasarkan data geologi yang memperlihatkan banyaknya struktur di daerah Pantar, pola anomali gradien horizontal tersebut diinterpretasikan sebagai respon dari banyaknya sesar-sesar minor di sekitar struktur utama, sehingga zona tersebut diduga memiliki permeabilitas yang sangat tinggi 


\section{MAKALAH ILMIAH}

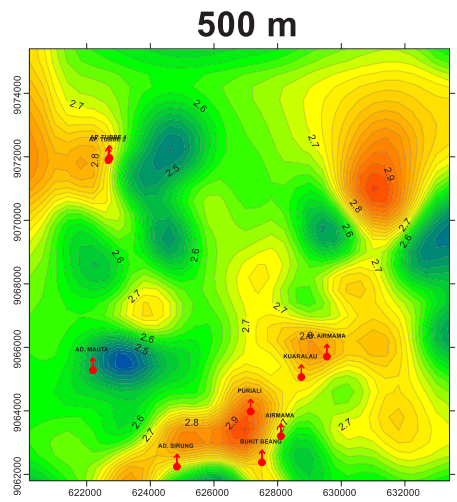

$2000 \mathrm{~m}$

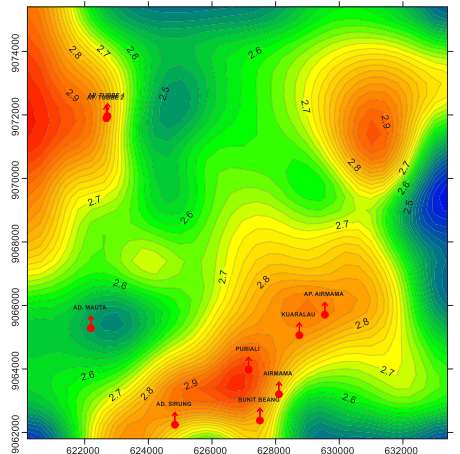

Gambar 5. Peta sebaran densitas batuan berdasarkan hasil pemodelan 3D

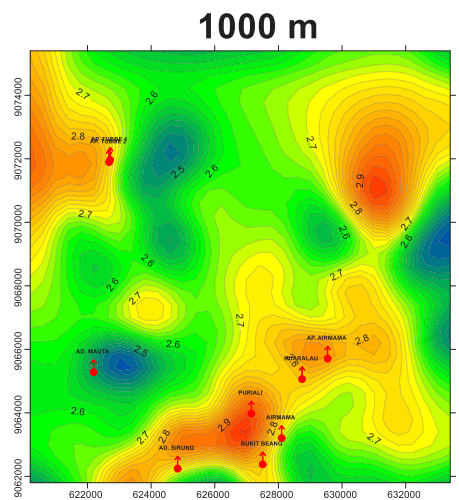

$2500 \mathrm{~m}$
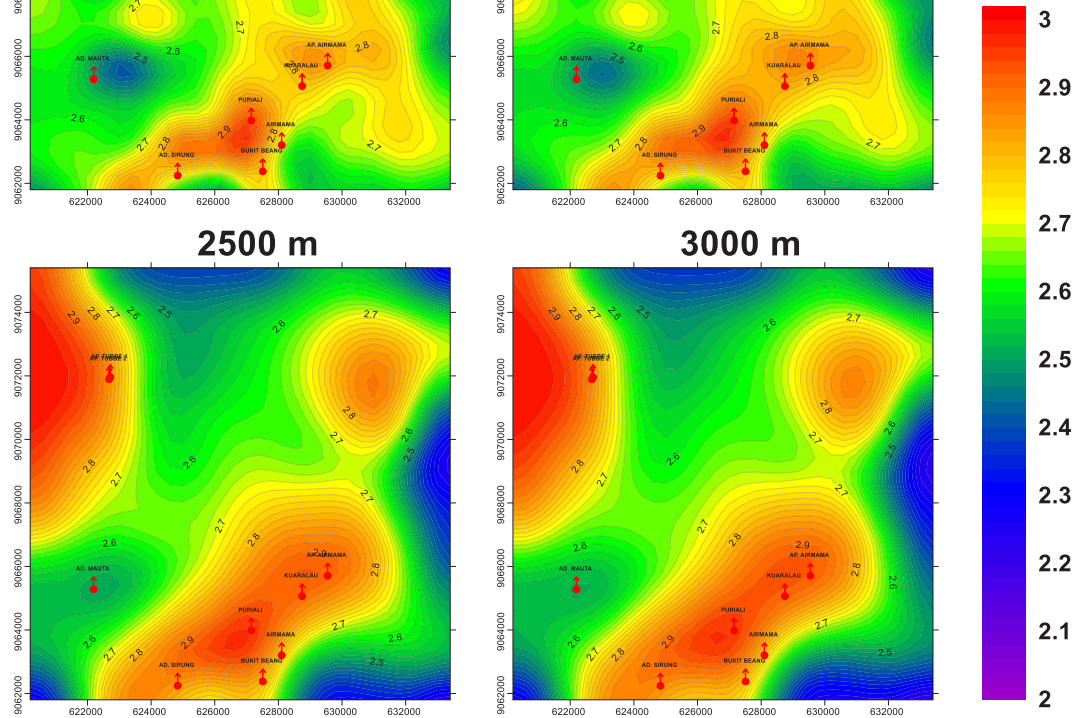

$\mathrm{gr} / \mathrm{cm}^{3}$
.9

\section{yang disayat pada kedalaman tertentu}

.

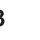
. (1)

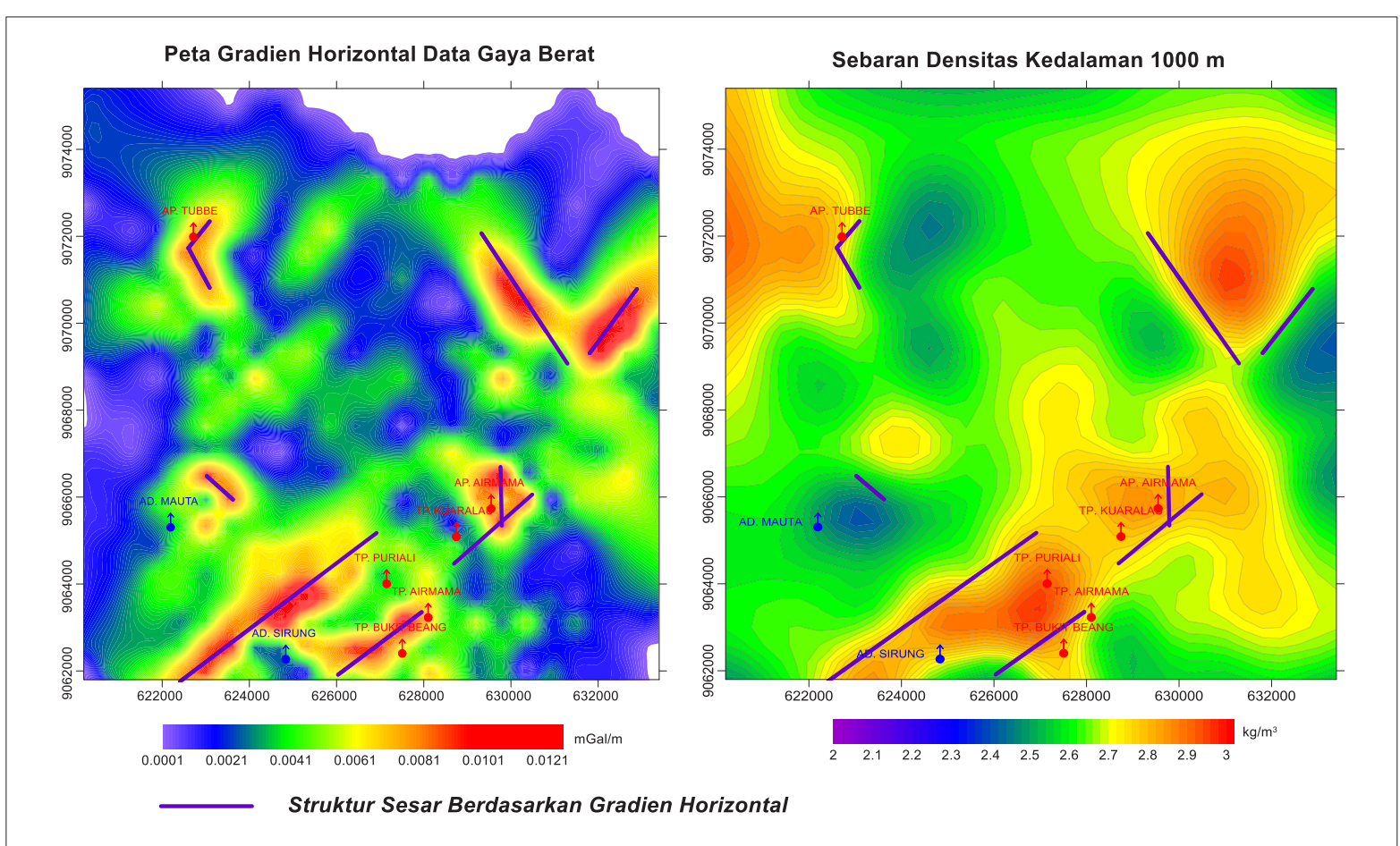

Gambar 6. Peta Hasil identifikasi struktur sesar berdasarkan gradien horizontal

Hasil pemodelan gaya berat 3D memperlihatkan adanya bodi berdensitas tinggi $>2,7 \mathrm{gr} / \mathrm{cm}^{3}$ dengan pola menerus dari daerah Sirung, Puriali, hingga ke Airmama. Penyebaran bodi berdensitas tinggi tersebut semakin luas seiring dengan bertambahnya 
kedalaman. Bodi dengan densitas tinggi tersebut diinterpretasikan sebagai lava atau batuan beku yang terbentuk akibat adanya aktivitas vulkanisme di sekitar Gunung Sirung. Bodi berdensitas tinggi juga ditemukan di sebelah baratlaut sekitar Tubbe yang juga diduga berasosiasi dengan lava atau batuan beku dan menjadi indikasi adanya sumber panas di kedalaman.

\section{KESIMPULAN}

Analisis gradien horizontal dan pemodelan 3D data gaya berat daerah panas bumi Pantar, memperlihatkan beberapa magnitudo maksimum yang berasosiasi dengan struktur sesar berarah baratdayatimurlaut yang terletak di sekitar daerah Puriali, Beang, dan Airmama. Struktur sesar tersebut diduga sebagai pengontrol utama sistem panas bumi di daerah Pantar.

\section{UCAPAN TERIMA KASIH}

Penulis menyampaikan apresiasi yang setinggi-tingginya kepada rekan-rekan di Bidang Panas Bumi Pusat Sumber Daya Mineral, Batubara dan Panas Bumi, yang telah banyak membantu dan berdiskusi dengan penulis, khususnya anggota tim Survei Gaya Berat dan Audio Magnetotelurik daerah panas bumi Pantar. Tidak lupa juga Penulis mengucapkan terima kasih kepada para editor dan mitra bestari yang telah memberikan banyak saran demi kesempurnaan makalah ini.

\section{DAFTAR PUSTAKA}

Anonim, 2001. Penyelidikan Pendahuluan Geologi dan Geokimia Potensi Panas Bumi, di Pulau Pantar, Direktorat Inventarisasi Sumber Daya Mineral Bandung.

Blakely, R.J., 1996. Potential Theory in Gravity and Magnetic Applications. Cambridge University Press.
Cordell, L., 1979. Gravimetric Expression of Graben Faulting in Santa Fe Country and the Espanola Basin, New Mexico, in Santa Fe Country, Ingersoll, R.V.; Woodward, L.A.; James, H.L.; [eds.], New Mexico Geological Society $30^{\text {th }}$ Annual Fall Field Conference Guidebook, $310 \mathrm{p}$.

Cordell, L., and Grauch, V. J. S., 1985. Mapping Basement Magnetization Zones from Aeromagnetic Data in the San Juan Basin, New Mexico, in Hinze, W. J., Ed., the Utility of Regional Gravity and Magnetic Anomaly Maps: Sot. Explor. Geophys., 181\&197.

Curewitz, D. dan Karson, J. A., 1997. Structural Settings of Hydrothermal Outflow: Fracture Permeability Maintained by Fault Propagation and Interaction. Journal of Volcanology and Geothermal Research, No. 79, p. 149-168.

Grauch, V.S.J. dan Cordell, L., 1987. Limitations of determining density or magnetic boundaries from the horizontal gradient of gravity or pseudogravity data. Short note, Geophysics, Vol. 52, No. 1, p. 118121

(http://dx.doi.org/10.1190/1.1442236).

Hadi, M.N. dan Kusnadi, D., 2015. Survei Geologi dan Geokimia Daerah Panas Bumi Pualu Pantar Kabupaten Alor, Provinsi Nusa Tenggara Timur. Prosiding Hasil Kegiatan Lapangan Pusat Sumber Daya Geologi Tahun Anggaran 2015. Bandung.

Hjelt, S. E., 1992, Pragmatic inversion of geophysical data. Springer-Verlag, Germany, $262 \mathrm{pp}$.

Kusumah, Y.I., Suryantini, dan Wibowo, H.H., 2010. Horizontal Derivative from Gravity Data as a Tool for Drilling Target Guide in Wayang Windu Geothermal Field, Indonesia. Proceedings World Geothermal Congress 2010. Bali, Indonesia. 
Nishijima, J. dan Naritomi, K., 2015. Interpretation of Gravity Data to Delineate Underground Structure in the Beppu Geothermal Field, Central Kyushu, Japan. Journal of Hydrology: Regional Studies (http://dx.doi.org/10.1016/j.ejrh.2015. 11.022).

Pirttijärvi, M., 2004. GRABLOX: Gravity interpretation and modelling software based on 3D block model.User's guide. Archive Report, Q 16.2/2004/2, Geological Survey of Finland, 39 pp.

Rahadinata, T. dan Takodama, I., 2015. Survei Terpadu Gaya Berat dan Audio Magnetotelurik (AMT) Daerah Panas Bumi Pantar, Kabupaten Alor, Provinsi Nusa Tenggara Timur. Prosiding Hasil Kegiatan Lapangan Pusat Sumber Daya Geologi Tahun Anggaran 2015. Bandung.

Rahadinata, T., Jaenudin, J., dan Risdianto, D., 2016. Survei Magnetotellurik (MT) dan Time Domain Electromagnetic (TDEM) Daerah Panas Bumi Pantar Kabupaten Alor, Nusa Tenggara Timur. Prosiding Hasil Kegiatan lapangan Pusat Sumber Daya Mineral Batubara dan Panas Bumi Tahun Anggaran 2016. Bandung.
Santos, P.A., and Rivas, J.A., 2009. Gravity Survey Contribution to Geothermal Exploration in El Savador: The Cases of Berlin, Ahuachapan and San Vicente Areas, United Nations University, Geothermal Training Programme.

Santoso, M.S., 1976. Inventarisasi Kenampakan Gejala Panas Bumi di Pulau Pantar dan Pulau Alor, Nusa Tenggara Timur, Direktorat Vulkanologi, Bandung.

Setyawan, A., Yudianto, H., Nishijima, J., dan Hakim, S., 2015. Horizontal Gradient Analysis for Gravity and Magnetic Data Beneath Gedongsongo Geothermal Manifestation, Ungaran, Indonesia. Proceedings World Geothermal Congress 2015, Melbourne, Australia. Sugianto, A. dan Rahadinata, T., 2015. Pemodelan Gaya Berat 3D Daerah Panas Bumi Dolok Marawa Kabupaten Simalungun, Sumatera Utara. Buletin Sumber Daya Geologi Vol. 10, No. 2, pp. 89-102.

Surmayadi, M., Heriwaseso, A., dan Karim, A., 2010. Peta Kawasan Rawan Bencana Gunungapi Sirung, Provinsi Nusa Tenggara Timur. Pusat Vulkanologi dan Mitigasi Bencana Geologi, Badan Geologi, Kementerian Energi dan Sumber Daya Mineral, Bandung.

\begin{tabular}{|ll|}
\hline Diterima & $:$ 06 Agustus 2017 \\
Direvisi & $:$ 30 Agustus 2017 \\
Disetujui & $:$ 31 Agustus 2017 \\
\hline
\end{tabular}

